\title{
Poinsettia Thrips, Impatiens Thrips (suggested common names) Echinothrips americanus Morgan (Insecta: Thysanoptera: Thripidae) ${ }^{1}$
}

\author{
Babu Panthi, Oscar Liburd, and Justin Renkema
}

\section{Introduction}

Echinothrips americanus Morgan is an important greenhouse foliage pest of vegetable and ornamental plants (Figure 1). This pest is polyphagous, reported from 48 plant families worldwide. The preferred hosts of Echinothrips americanus belong to the Araceae and Balsaminaceae plant families (CABI/EPPO 2014). This pest is native to eastern North America (Stannard 1968) and was first reported in 1984 on poinsettia, Euphorbia pulcherrima (Euphorbiaceae), in Georgia (Oetting 1987). Other important greenhouse crops damaged by this pest include Impatiens spp. (Balsaminaceae), gerbera, rose, sweet pepper, cucumber and eggplant (Vierbergen et al. 2006).

\section{Synonymy}

Echinothrips americanus Morgan was first described in 1913 from Indian poke, Veratrum viridae (Melanthiaceae), in Quincy, Florida, by Morgan, and in 1919 described by Watson as Dictyothrips floridensis Watson (Watson 1947), which was later synonymized by Hood (Hood 1927).

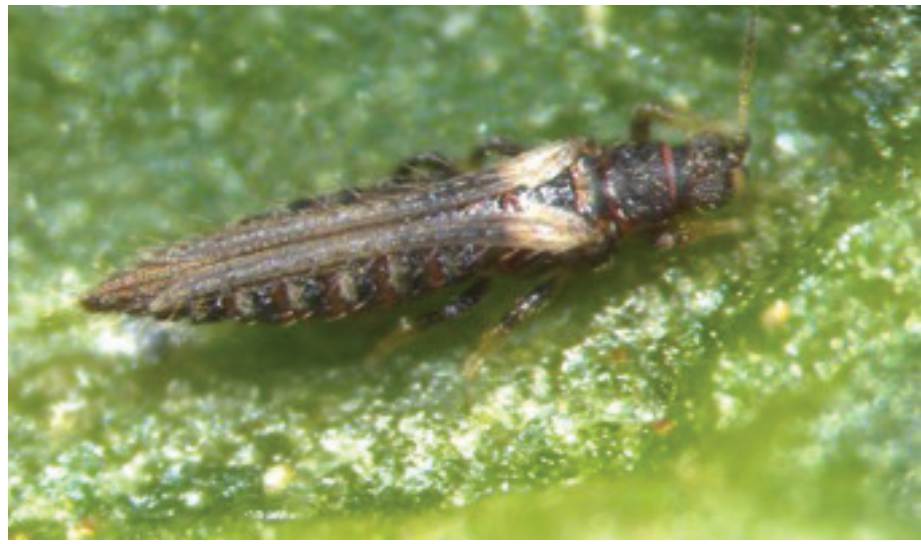

Figure 1. Adult poinsettia thrips, Echinothrips americanus Morgan (dorsal view).

Credits: Babu Panthi, UF/IFAS

\section{Distribution}

Native to eastern North America, Echinothrips americanus is found in the United States from Florida to New York and in Iowa on weedy plants (Vierbergen 1998). In 1984, Echinothrips americanus was first reported as a pest of greenhouse crops in Georgia (Oetting 1987). Outside its native range, this pest was first reported in Bermuda in 1927 (Nakahara and Hillburn 1989) and in Hawaii in 1981 (Mitchell 1983). In the Americas, Echinothrips americanus is present in Canada (Quebec and British Columbia), Mexico, and Puerto Rico, but is not yet established in

1. This document is EENY-730, one of a series of the Entomology and Nematology Department, UF/IFAS Extension. Original publication date May 2019. Revised December 2019. Visit the EDIS website at https://edis.ifas.ufl.edu for the currently supported version of this publication. This document is also available on the Featured Creatures website at http://entomology.ifas.ufl.edu/creatures.

2. Babu Panthi, graduate research assistant, Entomology and Nematology Department; Oscar Liburd, professor, Entomology and Nematology Department; and Justin Renkema, London Research and Development Centre, Agriculture and Agri-Food Canada/Government of Canada; UF/IFAS Extension, Gainesville, FL 32611.

The Institute of Food and Agricultural Sciences (IFAS) is an Equal Opportunity Institution authorized to provide research, educational information and other services

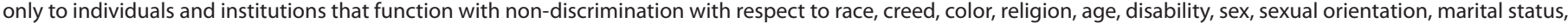

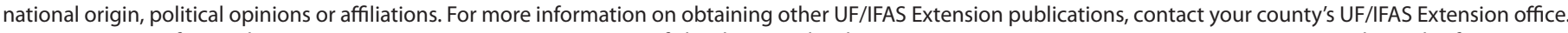
U.S. Department of Agriculture, UF/IFAS Extension Service, University of Florida, IFAS, Florida A \& M University Cooperative Extension Program, and Boards of County Commissioners Cooperating. Nick T. Place, dean for UF/IFAS Extension. 
California (Opit et al. 1997). In the United States, this pest is found in Illinois, Iowa, District of Columbia, Missouri, Maryland, Tennessee, Virginia, New York, Georgia, and Florida (CABI/EPPO 2011, EPPO 2014).

In Europe, the first report of this pest was from Syon Butterfly House, United Kingdom in 1989 (Collins 1989). Later, this pest was detected in the Netherlands in 1993 in shipments of Syngonium cuttings from the United States (Vierbergen 1998). Spread of Echinothrips americanus occurred rapidly across Europe between 1995 and 2005, and it is now present in 19 European countries. Echinothrips americanus was reported in central Russia in 2005 (Izhevskiy and Mironova 2008, Vierbergen et al. 2006). This pest was found in east Asia in 2003 and is currently found in Thailand, China (Mirab-balou et al. 2010), Japan (Itoh et al. 2003), Indonesia, and Taiwan (EPPO 2014). It has also been recorded from northeastern Australia (Mound et al. 2013).

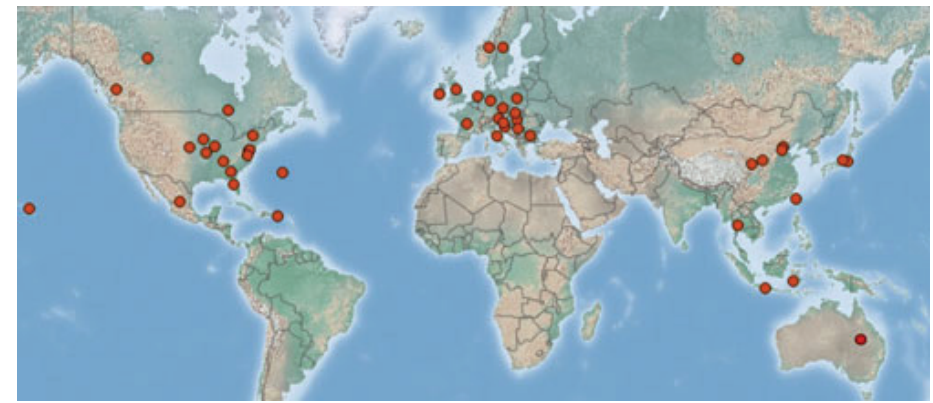

Figure 2. Map of geographic distribution of poinsettia thrips, Echinothrips americanus Morgan.

Credits: CABI/EPPO, 2011

\section{Description and Biology}

Female adult Echinothrips americanus are $1.6 \mathrm{~mm}$ long and male adults are $1.3 \mathrm{~mm}$ long. The general body color of adults is dark brown with red bands between abdominal segments. Adults have eight segmented antennae (I to VIII), segments I and II are dark brown, III and IV are light brown or yellowish, $\mathrm{V}$ has half basal color yellow, and VI to VIII are brown (Oetting and Beshear 1993, Trdan et al. 2003). Their wings are dark in color, pale gray at base and light brown in between middle and tip of wings. Immatures are white to pale-yellow. Echinothrips americanus has six developmental stages: egg, first and second instar larva, propupa, pupa, and adult. Echinothrips americanus are typically slow-moving compared with other active thrips like flower thrips and complete all life stages on the green tissue of plants. Both sexual and parthenogenetic reproduction occurs in Echinothrips americanus (Krueger et al. 2017).

\section{Egg}

An adult female inserts a single kidney-shaped egg $(0.2 \mathrm{~mm}$ long) inside the plant tissue, preferably on the underside of a leaf, with an average lifetime fecundity of 77 eggs (Oetting and Beshear 1993). The egg cannot be seen with the naked eye because it is inserted inside the plant tissue. Development time of egg is 13.8 to 17.4 days at $23^{\circ} \mathrm{C}$ on cucumber (Opit et al. 1997).

\section{Larva}

The first instar larva is white and clear, and the second instar is pale yellow. The larval stage occurs for four to eight days (Opit et al. 1997).

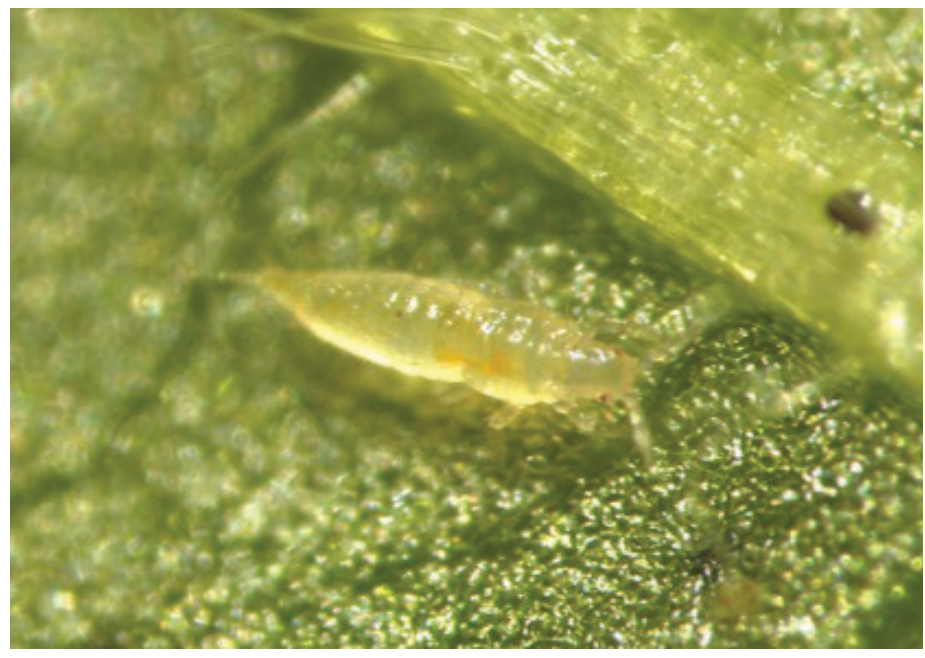

Figure 3. Larva of poinsettia thrips, Echinothrips americanus Morgan (dorsal view).

Credits: Babu Panthi, UF/IFAS

\section{Pupa}

The pupa progresses for two to six days through propupal and pupal stages, with both remaining inactive unless disturbed. Pupal stages, unlike larval stages, have visible, developing wing pads (Opit et al. 1997).

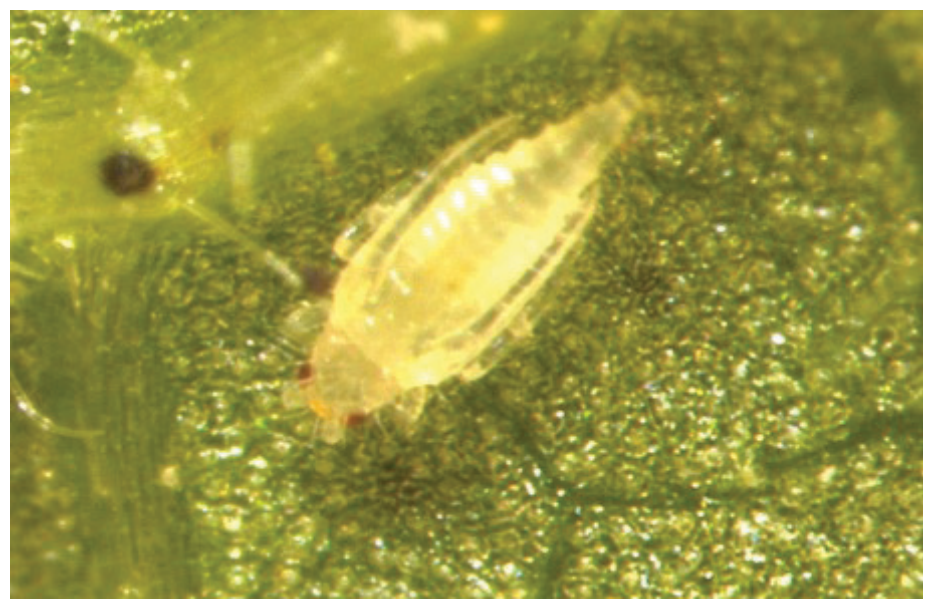

Figure 4. Pupa of poinsettia thrips, Echinothrips americanus Morgan (dorsal view).

Credits: Babu Panthi, UF/IFAS 


\section{Adult}

Mean longevity for an adult female is 41.3 days at $25^{\circ} \mathrm{C}$ (Vierbergen 1998), with development from oviposition to adult emergence over 33.9, 15.0 and 11.4 days at constant $20^{\circ} \mathrm{C}, 25^{\circ} \mathrm{C}$, and $30^{\circ} \mathrm{C}$ (Oetting and Beshear 1993).

\section{Hosts}

Echinothrips americanus is a leaf-dwelling insect, which feeds on either leaf surface, but they are more frequently found on the lower surface. This pest is polyphagous with a host range of 106 plant species in 48 families (Varga et al. 2010). In Georgia, Echinothrips americanus has been observed feeding and reproducing on 40 cultivated and 59 native plant species out of 51 cultivated and 75 native plants tested (Oetting 1993). Echinothrips americanus prefers greenhouse crops in the Araceae and Balsaminaceae families.

Common host plants are: Impatiens spp. (Balsaminaceae), Euphorbia pulcherrima (Euphorbiaceae), Dieffenbachia and Syngonium (Araceae), Cardamine hirsuta (Brassicaceae), and Hibiscus rosa-sinensis (Malvaceae).

\section{Economic Importance}

Larvae and adults puncture leaf cells with piercing-sucking mouthparts and consume the cell contents, injuring the leaf tissue and giving it a shrunken appearance (Figures 5 and 6) (Plant Health Australia 2001). Removal of chlorophyll from cells causes light spots on leaves. Echinothrips americanus can be detected by the presence of fecal droppings that appear as black specks on infested leaves. Echinothrips americanus may also feed on flowers. Recently, Echinothrips americanus have been reported as a serious pest of various greenhouse crops especially on ornamentals (Varga et al. 2010). This pest reduces the aesthetic value of ornamental plants by feeding on green tissue. Echinothrips americanus are not reported to transmit plant viruses.

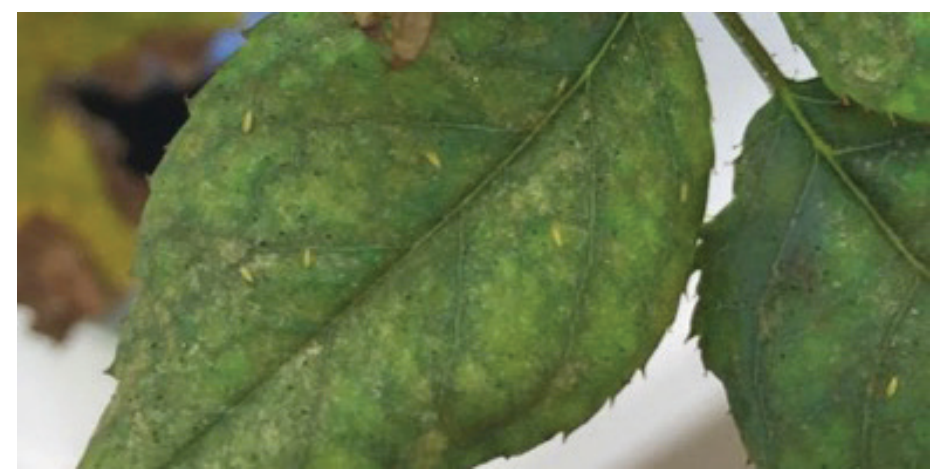

Figure 5. Feeding damage of poinsettia thrips, Echinothrips americanus Morgan, on greenhouse grown Knock Out ${ }^{\oplus}$ rose, Rosa radrazz (Rosaceae).

Credits: Babu Panthi, UF/IFAS

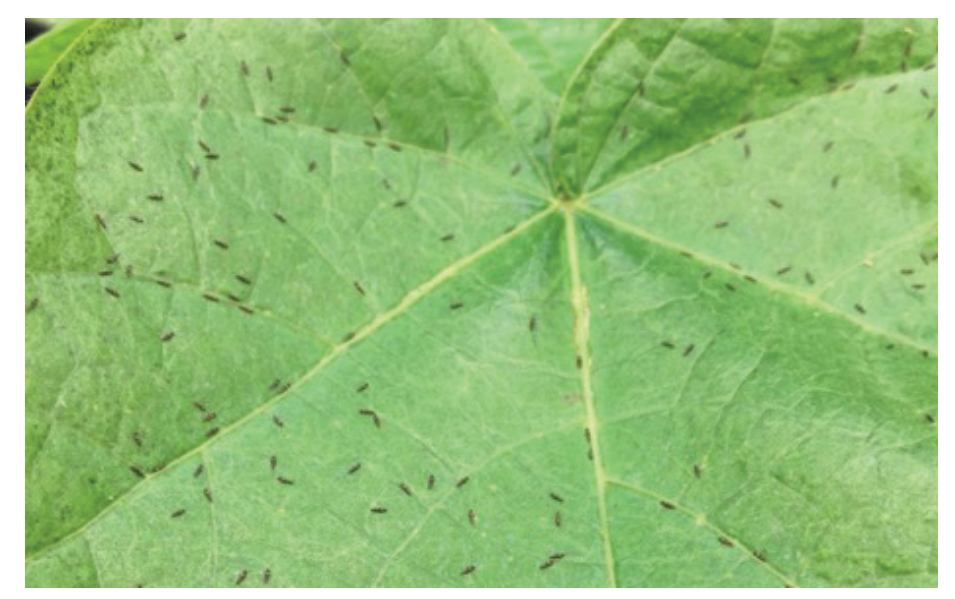

Figure 6. Adults of poinsettia thrips, Echinothrips americanus Morgan, feeding on greenhouse grown cotton, Gossypium hirsutum (Malvaceae).

Credits: Babu Panthi, UF/IFAS

\section{Management}

Echinothrips americanus is difficult to monitor using sticky cards because they are sedentary compared with other thrips such as flower thrips. Echinothrips americanus can be monitored by visually observing adult or larva, or through its feeding damage symptoms. All developmental stages of Echinothrips americanus remain on the plant. Therefore, weeds, plant remains, and leaf litter should be disposed of properly and in a timely manner because they may move and infest clean plants.

Several biological control agents are available to suppress populations of Echinothrips americanus. Commercially available predators that are effective are Orius majusculus (Reuter) (Hemiptera: Anthocoridae), Macrolophus pygmaeus (Rambur) (Hemiptera: Miridae), Dicyphus maroccanus Wagner (Hemiptera: Miridae), Dicyphus tamaninii Wagner (Hemiptera: Miridae), and Dicyphus errans (Wolff) (Hemiptera: Miridae) (Messelink et al. 2017). Lacewing (Chrysoperla rufilabris Burmeister) (Neuroptera: Chrysopidae) and predatory thrips (Franklinothrips spp.) (Thysanoptera: Aeolothripidae) are also suggested for Echinothrips americanus control (Figures 7 and 8) (UF/IFAS Control Guides 2000).

A study used the predatory phytoseiid mites (Acari: Phytoseiidae), Amblyseius swirskii (Athias-Henriot), Amblydromalus limonicus (Garman and McGregor), and Euseius ovalis (Evans) and found that when predators were provided with a supplement of pollen as food source, they provided better control of larval and pupal thrips compared with when no supplements were given (Ghasemzadeh et al. 2017; Opit et al. 1997). When this pest is present in greenhouses, it can be managed with insecticides, but populations on woody landscape plants are difficult to control. 


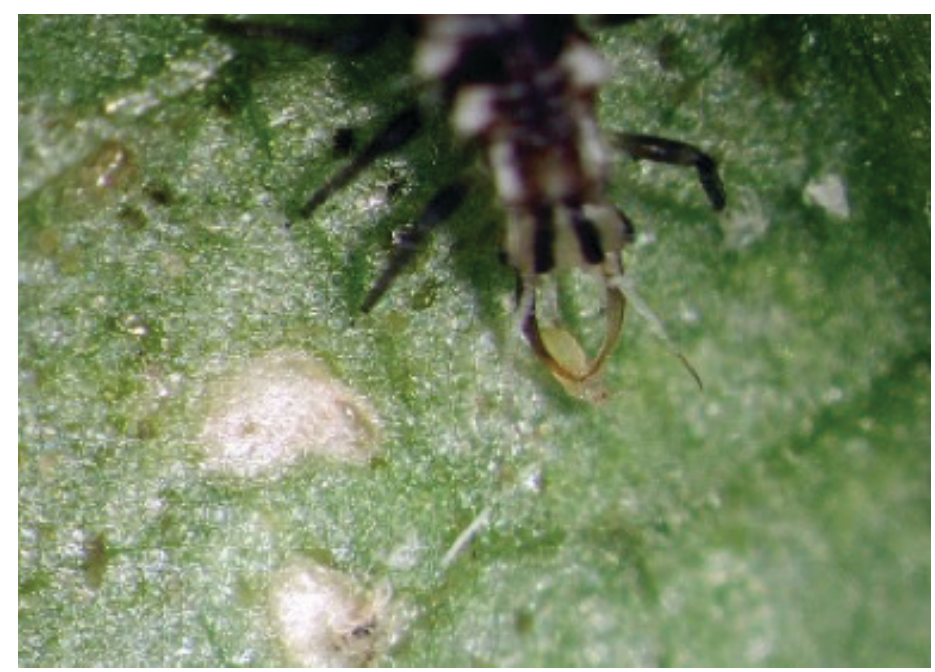

Figure 7. Larva of green lacewing, Chrysoperla rufilabris (Neuroptera: Chrysopidae), feeding on larva of poinsettia thrips, Echinothrips americanus Morgan.

Credits: Lance Osborne, UF/IFAS

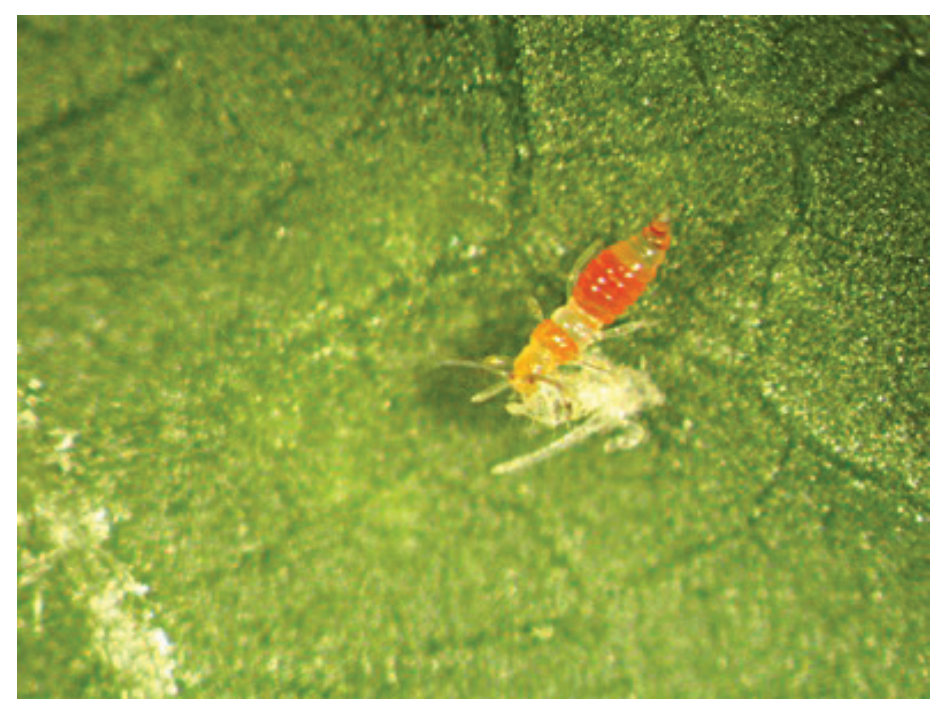

Figure 8. Larva of vespiform thrips, Franklinothrips

vespiformis (Thysanoptera: Aeolothripidae), feeding on larva of poinsettia thrips, Echinothrips americanus Morgan.

Credits: Lance Osborne, UF/IFAS

\section{Acknowledgements}

We thank Dr. Sriyanka Lahiri, Dr. Deepak Shrestha, and Dr. Karol Krey for reviewing this article and providing valuable input.

\section{Selected References}

CABI/EPPO. 2011. Echinothrips americanus. [Distribution map]. Distribution Maps of Plant Pests. Wallingford, UK: CABI, Map 748.
Collins DW. 1998. "Recent interceptions of Echinothrips americanus Morgan (Thysanoptera, Thripidae) imported into England." Entomologist's Monthly Magazine 134: 1-3.

EPPO. 2014. PQR database. Paris, France: European and Mediterranean Plant Protection Organization. Accessed on 01/10/2019. http://www.eppo.int/DATABASES/pqr/pqr. htm

Ghasemzadeh S, Leman A, Messelink GJ. 2017. “Biological control of Echinothrips americanus by phytoseiid predatory mites and the effect of pollen as supplemental food." Experimental and Applied Acarology 73: 209-221.

Hood JD. 1927. “A Blood-sucking Thrips.” Entomologist 9: $201 \mathrm{p}$.

Itoh K, Oguri A, Suzuki A. 2003. "Occurrence and control of insect pests in perilla on Aichi Prefecture." Proceedings of the Kansai Plant Protection Society 45: 71-72. (in Japanese)

Izhevskiy SS, Mironova MK. 2008. "First finds of Echinothrips americanus Morgan (Thysanoptera: Thripidae) on the territory of Russia." Russian Journal for Biological Invasions 1: 1-4 (in Russian, with English abstract).

Krueger S, Jilge M, Mound L, Moritz GB. 2017. "Reproductive Behavior of Echinothrips americanus (Thysanoptera: Thripidae)." Journal of Insect Science (Online) 17(2): 66.

Messelink GJ, Gasemzadeh S, Leman M. 2017. "Controlling Echinothrips americanus with predatory mites and bugs: growing problem in ornamentals under glass." In Greenhouses: The International Magazine for Greenhouse Growers 6: 12-13.

Mitchell WC. 1983. "Echinothrips americanus Morgan.” Proceedings of the Hawaiian Entomological Society 24: 192-193.

Mirab-balou M, Lu H, Chen XX. 2010. "First record of Echinothrips americanus Morgan (Thysanoptera: Thripidae) in mainland China, with notes on distribution and host plants." Acta Zootaxonomica Sinica 35(3): 674-679.

Morgan AC. 1913. "New genera and species of Thysanoptera, with notes on distribution and food plants." Proceedings of the United States National Museum 46: 1-55.

Mound LA, Tree DC and Sartiami D. 2013. "The greenhouse pest, Echinothrips americanus Morgan, recorded for the first time from Australia and Java." Myrmecia 49: 54-57. 
Nakahara S, Hilburn DJ. 1989. "Annotated checklist of the Thysanoptera of Bermuda." Journal of the New York Entomological Society 97: 251-260.

Oetting R. 1987. "Echinothrips americanus, a thrips of increased significance on ornamentals". In: Proceedings of the 32nd Southern Nurserymen Association Research Conference, pp 194-195.

Oetting RD, Beshear RJ. 1993. "Biology of the greenhouse pest Echinothrips americanus Morgan (Thysanoptera: Thripidae)." Advances in Thysanopterology 4: 307-315.

Opit GP, Peterson B, Gillespie DR, Costello RA. 1997. “The life cycle and management of Echinothrips americanus (Thysanoptera: Thripidae)." Journal of the Entomological Society of British Columbia 94: 3-6.

Oregon State University. 2014. Echinothrips americanus. Pacific Northwest Nursery IPM. Accessed on 01/10/2019. (http://oregonstate.edu/dept/nurspest/poinsettia_thrips. htm).

Plant Health Australia. 2001. Australian Plant Pest Database. Accessed on 01/10/2019. (http://www.planthealthaustralia.com.au/resources/australian-plant-pest-database/).

Stannard LJ. 1968. “The Thrips, or Thysanoptera, of Illinois." Illinois Natural History Survey Bulletin 29 (4).

Trdan S, Milevoj L, Raspudic E, Hehlina I. 2003. “The first record of Echinothrips americanus Morgan in Slovenia." Acta Phytopathologica et Entomologica Hungarica 38: 157-166.

University of Florida/IFAS Pest Control Guides. 2000. Echinothrips americanus Morgan. Accessed on 01/10/2019. (https://mrec.ifas.ufl.edu/lso/entomol/pestlinks/pestlink. htm).

Varga L, Fedor PJ, Suvák M, Kiseák J, Atakan E. 2010. "Larval and adult food preferences of the poinsettia thrips Echinothrips americanus Morgan, 1913 (Thysanoptera: Thripidae)." Journal of Pest Science 83: 319-327.

Vierbergen, 1998. "Echinothrips americanus Morgan, a new thrips in Dutch greenhouses (Thysanoptera: Thripidae).”

Proceedings of the Section Experimental and Applied Entomology of the Netherlands Entomological Society (N. E. V.) 9: 155-160.
Vierbergen G, Cean M, Hataláne SI, Jenser G, Masten T, Simala M. 2006. "Spread of two thrips pests in Europe:

Echinothrips americanus and Microcephalothrips abdominalis (Thysanoptera: Thripidae)." Acta Phytopathologica et Entomologica Hungarica 41: 287-296.

Watson JR. 1947. "Species of thrips described." The Florida Entomologist 30: 22-24. 